\title{
USING DEFERRED COMPENSATION TO STRENGTHEN THE ETHICS OF FINANCIAL REGULATION
}

\author{
Edward J. Kane \\ Working Paper 8399 \\ http://www.nber.org/papers/w8399 \\ NATIONAL BUREAU OF ECONOMIC RESEARCH \\ 1050 Massachusetts Avenue \\ Cambridge, MA 02138 \\ July 2001
}

For valuable comments on an earlier draft, the author wishes to thank Robert Eisenbeis, James Moser, Larry Wall, and two anonymous referees. The views expressed herein are those of the author and not necessarily those of the National Bureau of Economic Research.

(C) 2001 by Edward J. Kane. All rights reserved. Short sections of text, not to exceed two paragraphs, may be quoted without explicit permission provided that full credit, including (C) notice, is given to the source. 
Using Deferred Compensation to Strengthen the Ethics of Financial Regulation

Edward J. Kane

NBER Working Paper No. 8399

July 2001

JEL No. G2, G3, H4, K2

\begin{abstract}
Defects in the corporate governance of government-owned enterprises tempt opportunistic officials to breach duties of public stewardship. Corporate-governance theory suggests that incentivebased deferred compensation could intensify the force that common-law duties actually exert on regulatory managers. In principle, a forfeitable fund of deferred compensation could be combined with provisions for measuring, verifying, and rewarding multiperiod performance to make top regulators accountable for maximizing the long-run net social benefits their enterprise produces. Because government deposit-insurance enterprises are purveyors of credit enhancements for which private substitute and reinsurance markets exist, their performance could be measured accurately enough to make employment contracts for deposit-insurance CEOs a promising place to experiment with this kind of accountability reform.
\end{abstract}

Edward J. Kane

Finance Department

330 Fulton Hall

Boston College

Chestnut Hill, MA 02467

and NBER

Tel: 617-552-3986

Fax: 617-553-0431

Email: edward.kane@bc.edu 
Regulation and ethics are terms of art. Regulation consists of setting rules (in Latin, regula) and enforcing them. Enforcement entails monitoring and compelling regulatee conformance. External enforcement is sometimes characterized as supervision and may be assigned to parties whose interests differ substantially from those of the rulemakers. It is convenient to define "ethics" of regulation etymologically as occupational standards of performance that are imbedded in the customary ways of doing things that one may observe today in the community of actual supervisors and regulators (cf. Jackall, 1998). These practical standards tell us how to expect conflicts of interest inherent in particular regulatory duties to be resolved.

In modern societies, a financial institution is an organization that produces fundsmanagement, informational, and transactional products for a base of customers with whom it seeks to maintain a repeat-business relationship. Back-office elements of this business may be characterized as an information and dealmaking factory. Each deal obligates the counterparties to exchange a mix of information, cash, and service flows today and at specified future dates. To reliably value their side of potential deals, financial institutions gather, verify, and process information about the investment projects and creditworthiness of their counterparties. Through their capital structure and contracting instruments, institutions transmit accounting and other kinds of information about how existing deals allocate risk across their firm's explicit and implicit stakeholders.

The proximate goal of any financial regulator is to constrain the behavior of client financial institutions. Regulatory constraints supplement subtler limits that are set by social norms and by competitors in the markets in which institutions compete. 
To set bounds on the behavior of a financial firm requires regulatory officials to focus on its information flows and dealmaking activity. To establish even limited control over a universe of individual regulatees, financial regulators have to establish protocols for disclosure, truth-telling, promise-making, promise-keeping, and conciliation.

Particularly because of externalities associated with financial institutions' role in a country's payments system, most societies assign government financial regulators three major tasks:

(1) to limit risks of fraud, discrimination and contract nonperformance in financial transactions;

(2) to operate a safety net designed to virtually eliminate risks of fire-sale losses associated with financial-institution insolvencies and unjustified customer runs; and

(3) to operate the fraud controls and safety net honorably and at minimum opportunity cost to taxpayers.

These services offer benefits in confidence and convenience to regulated firms and to their customers. Minimizing the opportunity costs of producing regulatory benefits entails marginal-cost pricing for all services performed specifically for particular constituencies and balancing increases in uncompensated current expenditures on enforcement and compliance against the decreases such expenditures might induce in the projected costs of future financial messes and crises. The optimal balance may be defined as the equilibrium tradeoff that would obtain if it were possible to align the incentives of regulators perfectly with those of taxpayers. 
In choosing and operating a framework of rules and bureaucratic enforcement, the CEO of any regulatory enterprise faces three potential incentive conflicts. First, society usually assigns more than one mission to each regulatory enterprise. These separate missions may and sometimes do conflict with one another, allowing regulators to choose which ones to prioritize (Wall and Eisenbeis, 1999). Second, parties who might be harmed by a regulator's conscientious efforts to fulfill its social mission may be expected to find ways to retaliate against the personal and bureaucratic interests of the CEO. Especially when a problem is not yet publicly recognized, a regulator's short-term interests may be better served by a strategy of regulatory forbearance and coverup. Third, among top regulators job turnover is high. The brevity of a CEO's expected term of office implies a decisionmaking horizon that would on average overvalue the nearterm effects of policy strategies and may do so ever more heavily the longer a CEO stays in office. No one should suppose that political pressures for shortsighted policies can be neutralized merely by giving top office holders the option of serving a lengthy term in office. $^{1}$

It is convenient to analyze these incentive conflicts in a principal-agent framework. The ultimate principals are voter-taxpayers, for whom elected politicians and private and governmental regulatory agents act as fiduciaries or "public stewards" (Bear and Maldonado-Bear, 1993). Under common law, fiduciaries owe their principals duties of competence, loyalty, and care. These ethical duties oblige top regulators to exercise a high degree of vigilance and to strive energetically and fairly to protect their principals'

\footnotetext{
${ }^{1}$ For example, in the U.S., Governors of the Federal Reserve System are appointed to staggered 14-year terms. Nevertheless, it is rare for Governors to serve out a whole term. In fact, those whose terms do expire have often been appointed to serve only a fractional term.
} 
interests. Personnel screens, conflict-of-interest rules, and the need to enlist collusive partners limit the kinds of corruption we observe (Rose-Ackerman, 1979). However, coordination costs and federal law effectively insulate regulatory CEOs and boards from the threat of taxpayer lawsuits for engaging in negligent, deceptive, or manipulative behavior that arguably breaches these duties.

Ideally, the employment contracts under which top regulators function should be designed to minimize the costs generated by their agency relationship (Jensen and Meckling, 1976). An ideal contract would contain provisions measuring, verifying, and rewarding performance in ways that would render regulators fully accountable to taxpayers for maximizing the net social benefits their decisions produce.

This paper begins by reviewing how financial regulators create value and how defects in the corporate governance of government-owned enterprises tempt regulators to breach their duties of public stewardship. Subsequent sections explain how taxpayers could benefit from drawing on corporate-governance theory to intensify the incentive force that common-law duties actually exert on regulatory officials.

\section{Why External Regulators that Create Value in External Finance are Tempted to Distribute Regulatory Benefits Opportunistically}

As information and deal-making factories, financial institutions create value by supplying services that lower the costs that surplus and deficit spending units incur in negotiating and executing financial contracts. In intermediating flows of information between actual and potential counterparties, a financial institution not only collects, verifies, and analyzes information, it also moves the information it processes over 
internal and external communications networks. To keep its customers satisfied, an institution's services must be efficiently performed and the accuracy, security, and confidentiality of its information exchanges must be credibly maintained.

All modern societies regulate financial institutions and they do this for compelling reasons. Regulatory services generate net social value when they enhance transactional convenience and customer confidence in low-cost ways. Acting as trusted and disinterested outside parties, beneficent teams of private and governmental financial regulators can minimize coordination costs by: overseeing the accuracy and confidentiality of information flows to customers, harmonizing interfirm and network transactions, standardizing contracting protocols, and guaranteeing contract performance.

Although complying and monitoring compliance with specific restrictions is a costly process, regulation is on balance a valuable product because it generates aggregate benefits for society and/or for the industry being regulated and these benefits exceed their costs. It is the net benefits --and not the services themselves-- that customers and institutions value.

It is instructive to view financial services as a product that is supplied jointly by financial institutions and their regulators. This jointness in production means that international trade in financial services empowers customers to choose not just between domestic and foreign suppliers of financial products, but also between host-country and home-country systems of regulation. In financial services, customer choice focuses not just on the stand-alone capacity of the institutions with which the customer formally deals, but also on differences in the cost and quality of the supervisory and guarantee services on which informationally disadvantaged customers rely in assessing the liquidity 
and safety of the products selected. The value that regulated institutions can fairly attribute to the services of a given regulatory enterprise depend on the mix of purposes its regulatory CEO pursues and on the efficiency with which its managers accumulate and deploy enterprise resources. Of course, a regulator's resources include the value of whatever implicit and explicit government guarantees the enterprise can command.

\section{$\underline{\text { Regulatory Relationships }}$}

Like the financial-services business itself, financial regulation is a relationship business. Regulated institutions and their regulators contract to do a range of repeat business with each other for an indeterminate time. Although clients exert discipline on high-cost regulators by migrating their business to other producers of regulatory services, regulatory activity need not always be efficient in the short run. Neither party can recontract either moment to moment or transaction to transaction. If either side wishes to dissolve the relationship, it must absorb a substantial switching cost.

Public-choice theory emphasizes that regulation is not always intended to be socially benign. In particular, a regulator's ability to support and enforce cartel-like behavior among its clients subjects it to constant political pressure to produce subsidies and use its coordination powers to generate monopoly profits for incumbent institutions.

Figure One diagrams the contradictory pressures under which government regulators must operate. On the supply side of each regulatory relationship, regulators trade benefits to client "regulatees" for engaging in conforming behaviors and threaten to penalize nonconforming activity. Although regulatory services generate a mix of public, bureaucratic, and private benefits, officials are reluctant to acknowledge that incentive conflicts influence their policy decisions. This reluctance leads officials to employ "spin 
doctors" whose job is to credibly misinform taxpayer-voters about what is at stake in proposals to make changes either in financial rules or in enforcement practices.

On the demand side of the relationship, regulatees seek to influence regulators to make favorable adjustments in the net burden or subsidy that the regulatory framework generates. Although channels of taxpayer influence (such as an independent press and legislative oversight) are intended to promote the public interest, they may be subverted to intensify the incentive conflicts that make it hard for regulators to straightforwardly serve the public good. As in the U.S. savings-and-loan mess, self-seeking sectoral pressure on politicians and regulators often aggravates incentive conflicts. Firms' comparative advantage in building and exercising clout helps to explain why in practice consumer interests are often subordinated to producer interests (Stigler, 1971; Pelzman, 1976; Rose-Ackerman, 1979; Becker, 1983).

\section{Opportunistic Behavior and its Control}

Ethical norms of truth-telling, fair dealing, and promise-keeping express a simultaneous obligation to render good that is due to others and to avoid evil that would harm them. The force of this conception turns on the difficult-to-define italicized words. To operationalize the task of verifying violations of social norms, economists have developed the simpler concept of opportunism. An agent is said to be perfectly opportunistic if its choice of actions is based exclusively on its self-interest and is not influenced at all by a desire to respect social norms (Magill and Quinzii, 1996, p. 14). We may define a perfectly opportunistic regulator as one who would honor taxpayer interests only when it is in its self-interest to do so and would exploit any advantages the nonobservability and nonverifiability of its actions and character create. 
How much value a regulator creates and how beneficently this value is distributed depends on the incentives under which institutional managers and top regulators operate. These incentives vary across types of firms, across societies, and from era to era. In principle, regulatees are bound to offer hidden or laundered side payments to regulatory officials to tempt them to use their certification, coordination, and guarantee services in socially non-neutral ways. When these offers succeed, institutions may engage in the type of "crony capitalism" for which Indonesia has become the poster child. In such cases, the public interest to a greater or lesser degree is sold out by venal regulators. Speaking of the U.S., Auchincloss (1966, p. 9) observes: "So completely is it taken for granted that a man will prefer his own interest to that of his nation that our cabinet officers, men of the highest responsibility in the land, are advised to invest their private fortunes in government bonds."

In any society, the strength of a top regulator's temptations to act opportunistically is tempered by three mechanisms that partially substitute for and partially reinforce one another. Opportunism is mitigated first by social, cultural, and personal norms of honorable conduct and influenced further by how firmly these norms define and condemn regulator influence peddling and regulatee rent seeking. Moreover, on the hypothesis that gaining authority seldom helps one to becomes more ethical, the role of these norms is reinforced by recruitment processes that look explicitly for evidence of honorable and dishonorable behavior in a candidate's past. Second, postappointment opportunistic behavior is disciplined by watchdog institutions and enforceable criminal and civil sanctions against offering and taking laundered and unlaundered bribes. The more effective are society's norms, the looser it can efficiently 
allow its legal limits to be. Lessening legal constraints on dealmaking allows officials the discretion to undertake Pareto-improving transactions that might communicate a misleading impression of opportunistic decisionmaking. Finally, the scope for opportunism by top regulators is further restricted by their individual employment contracts and by the provisions of corporate governance that are in force at their particular regulatory enterprise.

In principle, managerial contracts can be designed to compensate for deficiencies in the ethical norms and legal sanctions under which regulatory officials operate. While designing and enforcing complex contracts is a costly process, society pays for weaknesses in public-service contracting by experiencing poorer and more-opportunistic regulatory decisions.

Rock (1999, p. 3) tells us that in private corporations, "executive pay packages contain four basic components: a base salary, an annual bonus tied to accounting performance, stock options, and long-term incentive plans (including restricted stock plans and multiyear accounting-based performance plans)." Samuelson's Principle of Revealed Preference indicates that these four elements are sufficient to span the space of stockholder-manager conflict.

The first two items are patently insufficient to span the contracting space. Given that managers may easily overstate accounting performance in the current period at the expense of a deterioration in longer-run results, contracting that focuses only on base salary and accounting measures of current performance is bound to be deficient. To complete the space over which taxpayers and regulatory CEOs contract, managerial compensation must also be conditioned on a social accounting of long-term performance. 
To protect conditioning provisions against managerial manipulation, internally produced measures of long-run regulatory performance must be supplemented to some degree by external measures of success and failure.

This paper suggests that performance-based deferred compensation can reduce at least some of the current incompleteness in the space over which taxpayers contract with regulatory officials.

\section{Corporate Governance of Private and Government Enterprises}

An organization is composed of changing individuals. To coordinate the behavior of those individuals for the benefit of a common enterprise requires channels of communication and control. In the simplest theory of collective risk-bearing within a firm, all stakeholders can costlessly observe and immediately verify the particular state of the world that obtains. This permits individuals to set up mechanisms for enforcing contingent contracts whose payoffs vary with the outcomes of enterprise decisions (Arrow, 1974). If enforcement were costless, contracting would be complete.

The real-world problems of executive compensation and corporate governance trace to differences in the ability of different individuals both to observe and verify firm performance and to enforce their contingent rights. These differences generate opportunities for stronger and better-informed parties to contract over future events in ways that victimize less-informed and weaker counterparties. A major issue in capitalstructure and corporate-governance theory is the possibility of using a firm's financial structure to protect outside creditors and minority shareholders from opportunistic 
behavior by controlling shareholders (Jensen and Meckling, 1976; Dewatripont and Tirole, 1994; Hart and Moore, 1994, 1998).

Corporate governance mechanisms determine how different stakeholders participate in firm decisions and how changes in the value created by these decisions get allocated among the stakeholders. These mechanisms generate constraints and options whose embrace gives managers and controlling shareholders lower funding costs in exchange for credibly bonding a willingness to treat less-informed stakeholders fairly.

The detailed capital structure of each firm simultaneously specifies its control structure and allocates future realized income in ways that vary contingently with the states of the world that unfold. The theory of corporate governance takes it for granted that a group of coordinated insiders obtains absolute control of every private corporation. The theory also takes it for granted that deficiencies in the ability of other stakeholders to observe, verify, and deter the opportunistic behavior of controlling insiders increase the extent to which corporate insiders behave opportunistically.

The tools of corporate governance consist of contractual devices that financial engineers have fashioned to determine how each firm's evolving economic performance feeds back upon insiders' decisions and control rights. Models of corporate governance seek to explain the mutual benefits of introducing contractual provisions that protect minority stakeholders by restraining opportunistic behavior by controlling insiders. By hypothesis, the purpose of the provisions is to minimize the costs of principal-agent conflict. Hence, in theory, every valid contractual protection efficiently redresses some deficiency in outsiders' ability to observe, verify, or deter adverse actions by insiders. 
This paper draws a correspondence between the governance of private and government corporations. Just as outside investor-stockholders have income and control rights in a private firm, taxpayer-voters have income and control rights in every government enterprise. In the United States, taxpayers are passive stockholders who can neither trade their shares nor directly elect the "corporate oversight board" of elected politicians to whom they are forced to delegate their control rights.

Congress decides how many different federal regulatory enterprises exist at any time and sets the scope of their authority. The regulatory structure of bureaucratic competition for regulatees influences how openly conflicts among regulatory goals are identified and in whose favor these conflicts are apt to be resolved (Wall and Eisenbeis, 1999). Other aspects of the governance of a government corporation resemble that of a private firm.

This paper studies the incentives that operate within an individual government enterprise when stockholder liability is unlimited. We assume that taxpayers will cover the economic insolvency of any government enterprise without limit if politicians bill them for it. We envision the bills as emanating from an oversight board consisting of the President and influential members of specialized Congressional oversight committees. The President appoints all enterprise CEOs with the advice and consent of other board members. Each board receives potentially disinformational annual reports of enterprise performance (which we term net "social earnings," $\Pi_{R}$ ) and may receive contingent campaign contributions from enterprise managers $\left(\mathrm{C}_{\mathrm{M}}\right)$. Board members also receive contingent campaign contributions from regulated firms $\left(C_{R}\right)$ and influential feedback from the press and taxpayers. Feedback matters if it communicates a threat to a 
committee member's reputation and re-electability or signals an adverse public perception of the net earnings or losses $\left(\Pi_{\mathrm{P}}\right)$ generated by the performance of the enterprise under his or her aegis. True social earnings are designated by $\Pi_{\mathrm{T}}$. True earnings in any period t consist of $\Pi_{R}(t)$ and whatever difference exists between the capitalized value $\mathrm{V}(\mathrm{t}-1)$ of true future earnings at the start of the period and the capitalized value of future earnings that obtains at $\mathrm{t}$ :

$$
\Pi_{T}(t)=\Pi_{R}(t)+V(t)-V(t-1)
$$

In principle, a corporate board's audit committee provides an independent evaluation of the performance information supplied by each firm's management, internal auditors, and external auditors such as the General Accounting Office. Committee members are asked to assess the competence and integrity of controlling managers, to reinforce the independence of outside auditors, and to assure that procedural difficulties inherent in asset valuation and itemization decisions do not distort accounting measures of firm condition and performance.

Accountants produce disinformation when and if they spin the facts that they report in a deliberate effort to lead less-informed observers to false conclusions. The tools of the disinformer are omission, exaggeration, mischaracterization, distortion, and distraction, backed up by techniques for exerting corrupting pressure on potential internal and external whistleblowers. The successful disinformer prevents unfavorable points from registering on accounting statements, overemphasizes favorable indicators and irrelevant issues, and deliberately misinterprets the summary implications of reported facts. 
Unfortunately, the incumbent politicians who effectively constitute a government enterprise's oversight board are not themselves incorruptible. They may be persuaded to shirk their auditing responsibilities and endorse disinformational accounting reports when and if they perceive a proposed coverup to promote their personal interests. Typically, this occurs under two conditions: (1) when releasing the information being covered up would directly or indirectly damage politicians' reputations and chances for re-election (for example, by negating support for projects valued by a politician's electoral constituency) and (2) when industry lobbyists back up their pressure for coverup with promises of substantial campaign contributions from regulatees and enterprise managers. In the model of taxpayer perceptions we present, it is understood that voters will eventually see through the smoke and mirrors of disinformational performance accounting. As in Kane (1996), this understanding reduces the durability of politicians' and corporate boardmembers' participation in any ongoing coverup. Incorporating Taxpayer Misperceptions into Corporate Governance

Although $\mathrm{V}(\mathrm{t})$ is not directly observable, we assume that regulators never understate their performance and that the public's perception of regulatory performance responds both to the time series of earnings reported in the past $\Pi_{R}(t-j)$ and to unspecified other evidence that helps them to recognize the cumulative amount of managerial misrepresentation that has been foisted upon them during the last $\mathrm{n}$ years:

$$
\Pi_{P}(t)=\Pi_{R}(t)+\sum_{j=t}^{t-n} \gamma_{t}\left[\Pi_{T}(j)-\Pi_{R}(j)\right](1+r)^{t-j} .
$$

In this model, $0<\gamma_{t} \leq \gamma_{t-1} \leq 1$ and $\mathrm{r}$ is the appropriate cost of capital. The model assumes that the true value of earnings prior to $t-n$ is known to everyone. 
The extent to which income is verifiable is parameterized by the vector $\gamma_{j}$ and the horizon $\mathrm{n}$. If $\mathrm{n}=0$ and $\gamma_{\mathrm{t}}=1$, enterprise income would be immediately verifiable. To be admissible, other lag distributions must embody the property that the ability of accounting gimmickry to hide losses experienced in any period deteriorates as time goes on and eventually disappears. One such distribution is:

$$
\gamma_{\mathrm{t}}=.2, \gamma_{\mathrm{t}-1}=.4, \gamma_{\mathrm{t}-2}=.6, \gamma_{\mathrm{t}-3}=.8, \gamma_{\mathrm{j}}=1 \text { for } \mathrm{j} \leq \mathrm{t}-4
$$

In the distribution given by (3), disinformation is only partially effective at the start and is completely neutralized in four years. ${ }^{2}$

We suppose that the decisionmaking horizon of each new regulatory CEO is $\mathrm{h}<\mathrm{n}$, and may become shorter as his or her term progresses. ${ }^{3}$ The assumed structure of information asymmetry makes it unwise for taxpayers to contract contingently over reported profits with a short-horizoned and potentially opportunistic regulatory CEO. In poor performance states, such a contract would strongly tempt even a moderately opportunistic CEO to overstate current regulatory performance. The CEO would do this, because he (or she) could rationally expect to escape to another job before events could bring the enterprise's disinformational reporting efforts fully to light and he could reasonably plan to deny responsibility for deterioration in accounting performance that surfaces after the CEO's departure. The more opportunistic the CEO's utility function

\footnotetext{
${ }^{2}$ The information structure we posit treats the $\gamma_{j}$ as constant and known to the CEO. Realistically, the efforts of oversight boards, outside watchdogs and traders to challenge disinformation may be expected to grow (and grow unpredictably) with the extent of the deception. This hypothesis would imply that, over time, the $\gamma_{j}$ would move closer to unity and $n$ might fall the more that performance is actually overstated.

${ }^{3}$ The multimember board structure used in the U.S. at the Federal Reserve and Federal Deposit Insurance Corporation makes the mean horizon of the group less variable than that of the CEO, thereby restraining endgame plays.
} 
and the longer on average the $\mathrm{CEO}$ believes the coverup can be sustained, the stronger this temptation will be in stressful times.

In a similar information environment, Hart and Moore $(1994,1998)$ and Dewatripont and Tirole (1994) show how a compatible incentive-compensation scheme can be fashioned. Their solution assigns a corporation's controlling managers claims to the income streams generated by appropriately structured securities issued by the firm. An earlier paper by Aghion and Bolton (1992) clarifies that the securities to be issued must carry both income and control rights. The essential feature of these optimalcontracting models is that the control rights of outsiders increase as the firm approaches and passes into insolvency (i.e., $\mathrm{V}_{\mathrm{t}} \leq 0$ ). The incentive force of this scheme comes from the nonlinear structure of the penalty — loss of future income and control rights - that the insiders suffer for poor managerial performance. Kaplan and Strömberg (1999) show that these models can explain the structure of the contracts used by U.S. venture capitalists.

To apply this research to a government enterprise, its social benefits and costs must be quantifiable to a reasonable degree. The literature on devising incentive contracts for monetary policymakers (e.g., Walsh, 1995; Beetsma and Jensen, 1999) suggests ways to link realizations of policy goals to compensation paid to top central bankers. However, this literature focuses on single-period realizations. As purveyors of government credit enhancements for which imperfect private substitutes such as private insurance and reinsurance exist, the opportunity-cost earnings of deposit insurers could be calculated in ways that would constitute a fair proxy for the multiperiod implications of their current regulatory decisions. 
The first implication of the corporate-contracting models is that a government deposit insurer should issue corporate debt backed exclusively by its earnings. Such a policy has already been recommended on intuitive grounds by Kane (1997) and articulated by Wall (1997). The second point is that the insurer's CEO must be required to take an appropriate position in enterprise debt. Kane (1997) suggests that in principle both of these conditions can be approximated by introducing a forfeitable fund of deferred compensation F for the CEO. In the simplest case, the CEO's right to this debt would be forfeited if an observable index of lagged performance (such as an operationally defined financial mess) were to occur within 3-to-5 years of the CEO's departure.

The model presented here provides a framework which can allow amounts less than $\mathrm{F}$ to be forfeited and which can trigger contingent partial forfeitures in a staged fashion. To promote value maximization, the size of the deferred-compensation fund should grow each year in proportion to the enterprise's reported social earnings.

By itself, this provision would encourage an opportunistic CEO to overstate the problems existing at the start of his tenure and to understate the problems left behind at the end. To address this difficulty, incoming CEOs might be authorized to appoint experts to audit the books of the enterprise and to submit differences in their assessment of the value to a three-person arbitration panel. As an additional check on the process, incoming CEOs might be allowed the option of refusing the job if they deem the arbitrators' decision to be sufficiently out of line.

The knowledge that hidden adverse information would be apt to surface during transitional audits -just when a CEO would be moving to another job-would promote 
interim truth-telling. This incentive could be reinforced by insisting that the CEO's fund be reduced by an amount proportional (or even more than proportional) to misvaluations associated with each and every misrepresentation that is eventually revealed to have occurred during the CEO's tenure. Finally, the money in the fund should not pass into the CEO's hands (i.e., the enterprise's debt should not mature) until enough years (n) have passed to destroy the effectiveness of any coverup in which the CEO might have participated.

\section{$\underline{\text { Start-Up Issues }}$}

Incentive compensation promises to increase an organization's productivity both by changing the character of the employees it attracts and retains and by improving the allocation of CEO and staff effort. Even at private firms, performance-based contracting exhibits bugs. Some may argue that society should eschew incentive compensation for government officials until the private sector has eliminated these bugs. Though plausible, the case for waiting must confront two counterarguments. First, waiting may well allow the best to become the enemy of the good. The evolutionary process of eliminating contractual bugs is unlikely to prove independent of government involvement in it. Immediately introducing contingent pay-performance sensitivity for even a single class of government regulatory officials would speed up the process of working the most serious bugs out of the system. It is not necessary to wait for someone to design a compensation package that can perfectly align the interests of the CEO and taxpayers. It is enough to improve incentive alignment in the short run in a way that can promise to induce further improvements over time. While initial schemes are bound to be imperfect, incentives for identifying and correcting contracting mistakes would be strong. Second, while society 
waits for better contracting protocols, the annual costs of incentive distortion are apt to grow. It is clear that incentive compensation schemes are spreading rapidly through the banking industry today (Hatch, 1995; Lutton, 1999). In a world in which regulatees regularly offer politicians and regulators laundered side payments, it is dangerous to assign government officials responsibility for regulating private behaviors that are growing progressively more incentive-driven without at the same time giving these officials an incentive-driven financial stake in regulatory outcomes.

Any effort to operationalize our proposal must confront the fact that neither $\mathrm{n}$ nor the $\gamma_{j}$ are strictly knowable today. In implementing any abstract model, users must rely on applied econometricians to test and devise concrete methods for estimating unobservable parameters. It would be wise to use robust statistical methods and approximate the unknown lag distributions and parameters in a flexible way.

However, whatever a plan's initial defects, once society offers a deferredcompensation scheme to any regulatory $\mathrm{CEO}$, incentives for improving the informativeness of performance reporting at regulatory enterprises will be strengthened greatly. Once a deferred-compensation scheme is put in place, its concrete existence would shorten $\mathrm{n}$ and push individual $\gamma_{\mathrm{j}}$ toward unity. Weaknesses in performance reporting would result in excessive compensation being explicitly disbursed. Excessive disbursements to a departed CEO would disadvantage the successor CEO unless the mismeasurements of performance responsible for the overpayment were identified and recalibrated. To fairly initialize his or her deferred-compensation option, each new CEO would have a powerful incentive to promptly uncover and convincingly reveal whatever enterprise losses predecessors had tried to conceal. 
The incentive for each new CEO to set the record straight would also change the incentives facing the politicians on the oversight board. They would now be reputationally accountable for insisting that systems for reporting performance information to them be made as transparent as technologically possible. To shield themselves from being made to look bad by facts that are apt to be revealed by new CEOs, politicians would want to direct the General Accounting Office, the Congressional Budget Office, and the Office of Management and Budget to undertake and support research aimed at developing ever-better measures of the opportunity costs of relevant kinds of regulation.

During the scheme's shakeout period, this research and associated contracting protocols would be progressing rapidly. Until the information environment stabilized, politicians' self-interest should leave them reluctant to grant any ex-CEO premature access to their pool of deferred compensation. This is because evidence that politicians had approved of paying excessive compensation to a demonstrably unworthy official would generate the kind of juicy scandal that the American press lives for.

\section{Defects in Current Congressional Constraints on Regulatory Duty}

Regulation entails layered conflicts between managers of each regulatory enterprise, client regulatees, elected politicians, and taxpayers. To supervise troubled institutions efficiently, deposit insurers must fulfill four common-law duties that they owe taxpayers:

1. Vision (i.e., to develop and maintain a capacity to spot aggressive on-and offbalance sheet risk-taking and capital shortages as soon as they occur); 
2. Prompt corrective action (to control the value of implicit and explicit guarantees);

3. Least-cost resolution (of economic insolvencies that corrective action fails to avert); and

4. Truth-telling (about the opportunity costs of their regulatory performance).

The Federal Deposit Insurance Corporation Improvement Act of 1991 (FDICIA) establishes regulatory accountability only for the second and third of these duties. This incompleteness in focus tempts CEOs to allow leeway inherent in cash-flow accounting to promote private interests by subverting their informational duties of vision and truthtelling.

Violating the duty of vision makes it easier for banks to keep regulators at an informational disadvantage. However, in exchange for preserving their clients' informational edge, regulators receive an option of credible ex post deniability for bad outcomes. Maintaining impaired vision allows them to blame the industry for hiding actions that turn out to have disastrous consequences.

Violating the duty of truth-telling enables regulators to keep themselves better informed than taxpayers and politicians. In exchange for allowing top regulators to overstate the effectiveness of their policies, politicians that choose to serve opportunistically on a regulator's oversight board receive an option to blame the CEOs when trouble surfaces for hiding information from them.

The incentive compatibility of this scapegoating scheme depends on the imperfect observability of corrupting side payments between regulatees, politicians and regulators and on the twin blockages in the flow of performance information to regulators and 
taxpayers. If information flowed freely to all parties, the politicians on the oversight board would be immediately embarrassed anytime they too loosely enforced FDICIA's duties of prompt corrective action and least-cost resolution. Similarly, deposit-insurer CEOs would face public censure if they dared to allow economic insolvencies among their clients to fester and cumulate into a systemic crisis. Even without observing the side payments, the press could infer that the interests of taxpayers were being poorly served.

\section{Conclusion}

This paper focuses on the problem of improving public-service managerial contracts by reducing the temptation to opportunistic behavior that existing information asymmetries pose. It proposes a way for taxpayers to offset the unethical incentive compensation that financial institutions may be expected to offer in exchange for regulatory subsidies. An advantage of this contracting solution is that it can compensate for gaps in politicians' half-hearted efforts to identify and outlaw unethical campaign contributions and other forms of laundered side payments.

The globalization of financial markets and institutions tends to heighten competition between alternative regulatory systems (Kane, 1999). While heightened international competition tends to displace poor systems of regulation by better ones, the maximal effective improvement in any country is limited by the level of the best-practice regulation that can be found elsewhere.

To markedly boost the level of best practices requires fundamental improvements in the corporate governance of government regulatory enterprises. A feasible start in this 
direction is to intensify the incentive force of the duties officials owe taxpayers by instituting a scheme of forfeitable deferred compensation for heads of deposit-insurance enterprises. An ideal deferred-compensation scheme would simultaneously increase the human-capital risk that individual CEOs would face for tolerating poor performance and offer just compensation to every CEO willing to conscientiously embrace this risk. 


\section{REFERENCES}

Aghion, Phillippe, and Patrick Bolton, 1992. An Incomplete Contracts Approach to Financial Contracting. Review of Economic Studies 77, 338-401.

Arrow, Kenneth J., 1974. The Limits of Organization. W.W. Norton \& Company, New York.

Auchincloss, Louis, 1966. The Embezzler. Dell Publishing Co., New York.

Bear, Larry A., and Rita Maldonado-Bear, 1994. Free Markets, Finance, Ethics, and Law. Prentice-Hall, Englewood Cliffs.

Becker, Gary, 1983. A Theory of Competition Among Pressure Groups for Political Influence. Quarterly Journal of Economics 98, August, 371-400.

Beetsma, Roel, and Henrik Jensen, 1999. Optimal Inflation Targets, "Conservative" Central Banks, and Linear Inflation Contracts: Comment. American Economic Review 89, March, 342-347.

Dewatripont, Matthias, and Jean Tirole, 1994. A Theory of Debt and Equity: Diversity of Securities and Manager-Shareholder Congruence. Quarterly Journal of Economics 109, November, 1027-1054.

Hart, Oliver, and John Moore, 1994. A Theory of Debt Based on the Inalienability of Human Capital. Quarterly Journal of Economics 109, November, 841-879. , 1998. Default and Regulation: A Dynamic Model of Debt. Quarterly Journal of Economics 113, February, 1-41.

Hatch, James A., 1995. Banks Lead in Linking Top Execs' Pay to Performance. American Banker 160, July 24. 
Jackall, Robert, 1988. Moral Mazes: The World of Corporate Managers. Oxford University Press, New York.

Jensen, Michael, and William Meckling, 1976. Theory of the Firm: Managerial Behavior, Agency Costs, and Capital Structure. Journal of Financial Economics 3, October, 305-360.

Kane, Edward J., 1996. De Jure Interstate Banking: Why Only Now? Journal of Money, Credit, and Banking 28, May, 141-161. , 1997. The Ethical Foundations of Financial Regulation. Journal of Financial Services Research 12, August, 51-74. , 1999. How Offshore Financial Competition Disciplines Exit Resistance by Incentive-Conflicted Bank Regulators. Journal of Financial Services Research 16, No. 2/3, 265-291.

Kaplan, Steven N., and Per Strömberg, 1999. Financial Contracting Theory Meets the Real World: An Empirical Analysis of Venture capital Contracts. Graduate School of Business, University of Chicago, July.

Lutton, Laura P., 1999. Mellon Latest Bank to Offer Rank and File Stock Options Carrot. American Banker 164, June 22.

Magill, Michael, and Martine Quinzii, 1996. Theory of Incomplete Markets, Vol. I, MIT Press, Cambridge.

Murphy, Kevin J., 1999. Executive Compensation. University of Southern California, Los Angeles, June.

Pelzman, Sam, 1976. Toward a More General Theory of Regulation. Journal of Law and Economics 19, April, 211-241. 
Rose-Ackerman, Susan, 1979. Corruption: A Study in Political Economy. Academic Press, New York.

Stigler, George, 1971. The Theory of Economic Regulation. Bell Journal of Economics 1, Spring, 3-21.

Wall, Larry, 1997. Taking Note of the Deposit Insurance Fund: A Plan for the FDIC to Issue Capital Notes. Economic Review, Federal Reserve Bank of Atlanta 82, First Quarter, 14-31.

Wall, Larry, and Robert Eisenbeis, 1999. Financial Regulatory Structure and the Resolution of Conflicting Goals. Journal of Financial Services Research 16, Nos. 2-3, forthcoming.

Walsh, Carl E., 1995. Optimal Contracts for Central Banks. American Economic Review 81, March, 150-167. 


\section{Figure One: CHAIN OF DELEGATION IN FINANCIAL REGULATION}

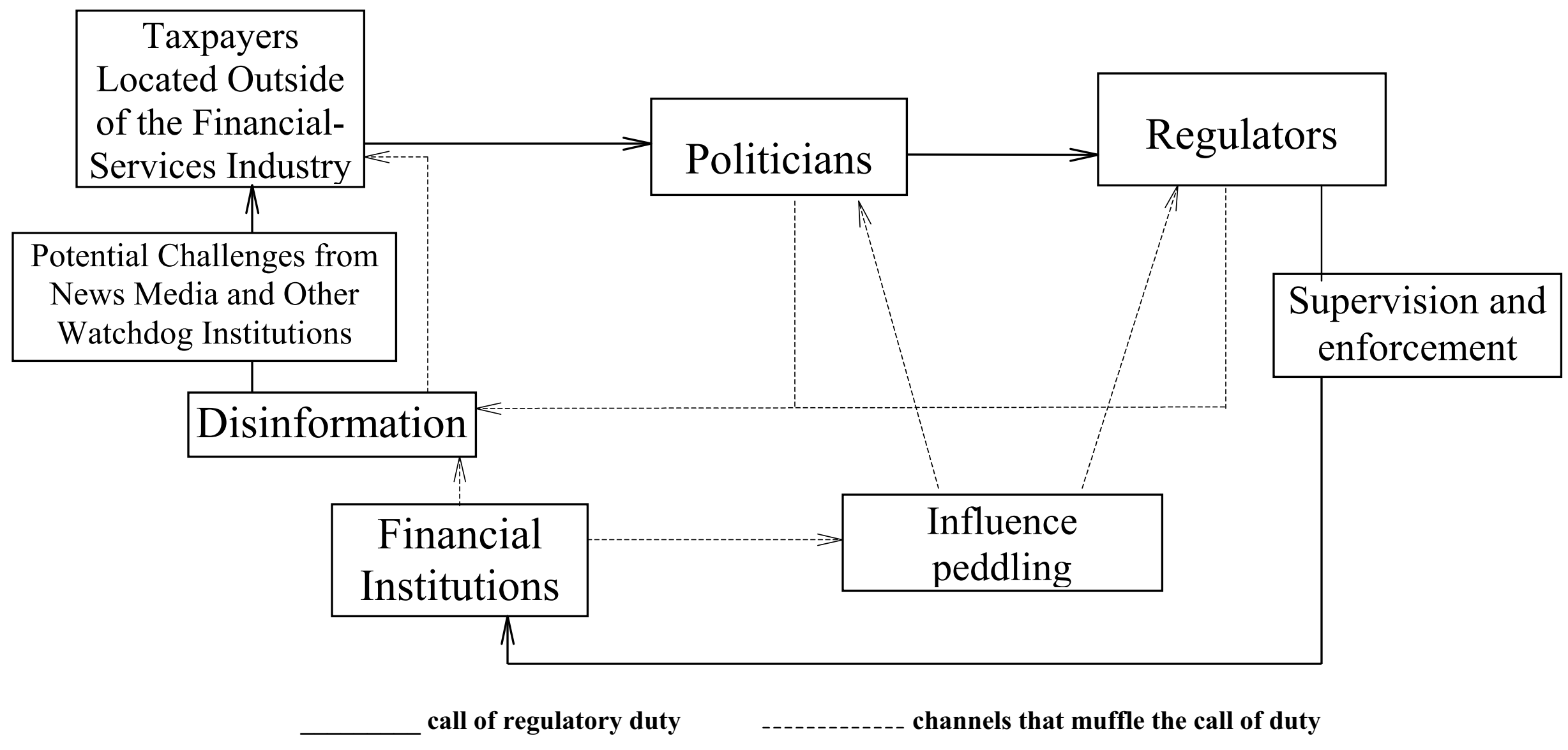

